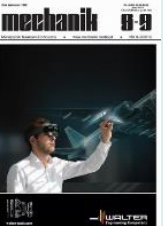

\title{
Evaluation of surface asperities and tool wear after turning with use of a focus variation microscope
}

\author{
Ocena nierówności powierzchni toczonej i zużycia ostrza \\ z wykorzystaniem mikroskopu różnicowania ogniskowego
}

\section{MICHAK MENDAK \\ MICHAŁ WIECZOROWSKI \\ KAROL GROCHALSKI \\ BARTOSZ GAPIŃSKI *}

The authors examined the shaft machined in $100 \mathrm{Cr} 6$ steel with four different feeds per revolution using round carbide inserts. After each session, the insert was subjected to measurement, and, finally, roughness of the entire shaft was measured. The obtained results were then analyzed and the roughness and wear data of the tools were presented.

KEYWORDS: surface asperities, tool wear analysis, turning, focus variation microscope

Surface irregularities of workpieces in the turning process have been the subject of many studies [1-3]. For the most part, these studies used a profile method, so on one hand they were characterized by a high resolution of the measurement, and on the other hand, they were susceptible to the randomness of the profile's distribution on the tested surface. Currently, surface asperities measurements are leaning towards areal measurements [4].

Due to the capability for accurate and reliable measurement of the machined surface $[5,6]$, Alicona InfiniteFocus G5 and SL focus variation microscopes were used. These microscopes were also used to measure the microgeometry of cutting tools and to determine the degree of their wear on the basis of the deviation map created.

The measurement of surface irregularities and tool geometry was carried out using the focus variation method, which ensures a very high vertical resolution. Measuring unevenness in relation to the entire surface, and not only to the profile, enables a more detailed analysis of the form of the treated surface.

\section{Focus Variation}

The focus variation microscope uses lenses with very low depth of field. For the needs of the measurement, the range of scanning in the $Z$ axis is set, which ensures complete bilateral defocus of the image. During the scanning motion, the contrast between neighboring pixels is measured continuously, and the position in the coordinate system for each pixel is determined from the course of changes in its value.

\footnotetext{
* Mgr inż. Michał Mendak (michal.a.mendak@doctorate.put.poznan.pl) prof. dr hab. inż. Michał Wieczorowski (michal.wieczorowski@put. poznan.pl), mgr inż. Karol Grochalski (karol.grochalski@put.poznan.pl), dr inż. Bartosz Gapiński (bartosz.gapinski@put.poznan.pl) - Politechnika Poznańska, Instytut Technologii Mechanicznej, Zakład Metrologii i Systemów Pomiarowych
}

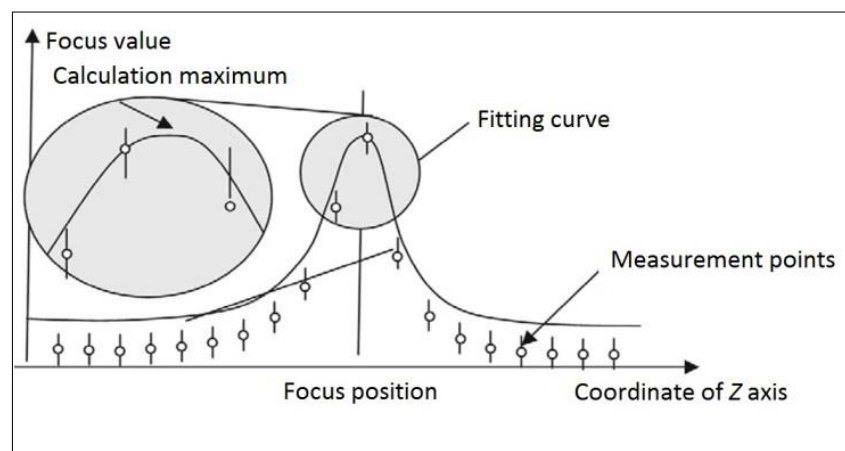

Fig. 1. Graphical representation of the procedure for determining the coordinate of a sharp point [7]. The position of the point is obtained in the software process of calculating the maximum value of the fitted focus curve [7]

\section{Course of research}

The subject of the research was a shaft made of $100 \mathrm{Cr} 6$ steel, turned into a DMG MoriSeiki CTX 310 Ecoline turning center with a constant cutting speed $v_{\mathrm{c}}=150 \mathrm{~m} / \mathrm{min}$, without the use of coolant. The machining of the shaft fragment was carried out at four different feed speeds on the stock to observe changes in the unevenness of the treated surface and changes in the tool geometry. Each fragment had a length of approx. $30 \mathrm{~mm}$. Before and after each operation, the WG 300 cutting insert was measured using the InfiniteFocus $S L$ focus variation microscope, to be able to analyze wear and changes in the tool geometry later. After machining of the entire shaft, microscopic measurements of surface irregularities were made in each of the four areas. A report was prepared for each measurement of the cutting insert, including rounding values of the cutting edge. General machining conditions are presented in the table.

TABLE. Machining conditions, detailing machined material and cutting insert

\begin{tabular}{|l|c|c|c|c|}
\hline Stage & I & II & III & IV \\
\hline $\begin{array}{l}\text { Feed per revolution } f_{n}, \\
\text { mm/obr }\end{array}$ & 0.13 & 0.092 & 0.075 & 0.25 \\
\hline Cutting speed $v_{c}, \mathrm{~m} / \mathrm{min}$ & \multicolumn{4}{|c|}{150} \\
\hline Cutting depth $a_{\mathrm{p}}, \mathrm{mm}$ & \multicolumn{4}{|c|}{0.1} \\
\hline Cutting length, $\mathrm{m}$ & 30.4 & 43.0 & 52.8 & 15.8 \\
\hline Cutting material & \multicolumn{4}{|c|}{ Steel 100Cr6 } \\
\hline Blade & \multicolumn{4}{|c|}{ WG-300 round plate, ceramic } \\
\hline
\end{tabular}




\section{Analysis of results}

The use of the focus variation microscope allowed efficient measurement of the tested surface and the separation of several hundred profiles in a much shorter time (about 2 minutes) than in the case of a conventional contact profilometer. The obtained surface models (fig. 2) were leveled and the dominant form (cylinder) was removed.

Fig. 2 and fig. 3 show average values of roughness parameters and spatial parameters of surface irregularities. The parameters $R a, R q$ and $R z$ were calculated in the MountainsMap program on the basis of 340 profiles evenly distributed over the entire measurement surface. The lowest values of all parameters (except for $R a$ ) were noted for the first stage $\left(f_{n}=0.13 \mathrm{~mm} / \mathrm{rev}\right)$. A general tendency of the decrease in the value of the surface asperities characteristics is visible along with the increase of the feed value per revolution. Determining the exact point of reversal of this tendency would require a larger number of tests. The ranges are relatively consistent in their course. Higher values of spatial parameters with respect to corresponding roughness parameters are noticeable. Fig. 3 shows a significant increase in the $S z$ parameter for stage II $\left(f_{n}=0.092 \mathrm{~mm} / \mathrm{rev}\right)$, which has not been registered when measuring profiles. This is most likely caused by the distribution of roughness profiles on the surface, which bypassed the location of this inequality, which consequently underestimated the measurement result.

The obtained 3D models of the cutting insert were placed on each other and in special software a map of deviations from the nominal geometry [8] was created, i.e. the model obtained from measuring the new insert. Surface fitting took place by the best-fit method.

Fig. 4 shows the effect of such an operation using the nominal model and after the fourth processing stage. Geometry deviation values are given in the normal direction to the nominal surface. There are visible accretions on the cutting edge and on the flank surface, as well as the concentration of geometry changes on a certain section of the flank surface and in the direct proximity of the edge, and fringe-like set of geometry deviations along the machining direction. Similar system of asperities can be seen on the surface image of the shaft in fig. 5 . There are also individual grooves (blue).

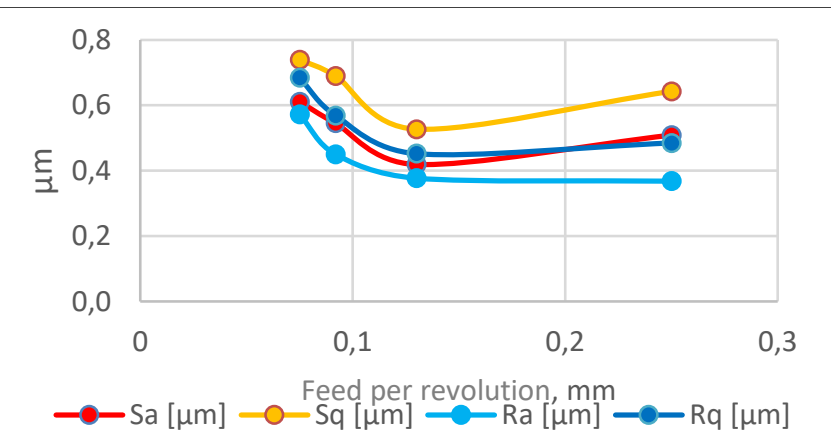

Fig. 2. Values and course of changes in parameters $R a$, Sa and $R q$ and $S q$

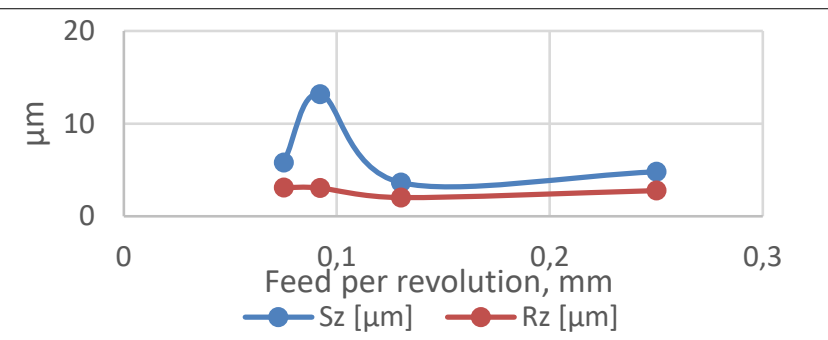

Fig. 3. Values and course of changes in spatial parameters $S z$ and $R z$

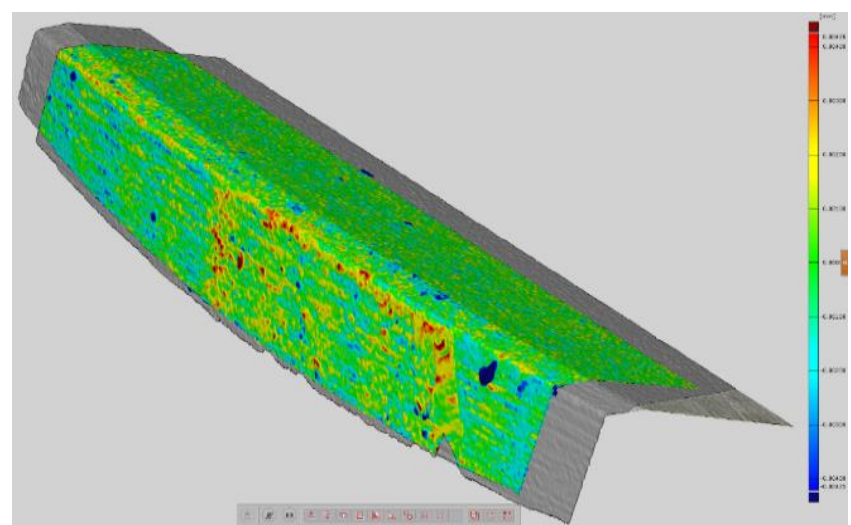

Fig. 4. Map of geometry deviations of the cutting edge. The deviation values shown are in the range from $-4 \mu \mathrm{m}$ (blue fields) to $4 \mu \mathrm{m}$ (red fields)

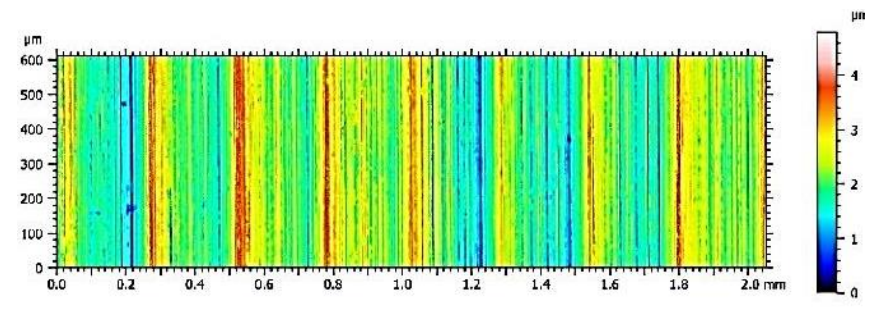

Fig. 5. Image of the surface after the fourth stage of processing, obtained with a focus variation microscope. Surface leveled, shape removed. Sampling resolution: $0.64 \mu \mathrm{m}$, vertical resolution: $0.021 \mu \mathrm{m}$

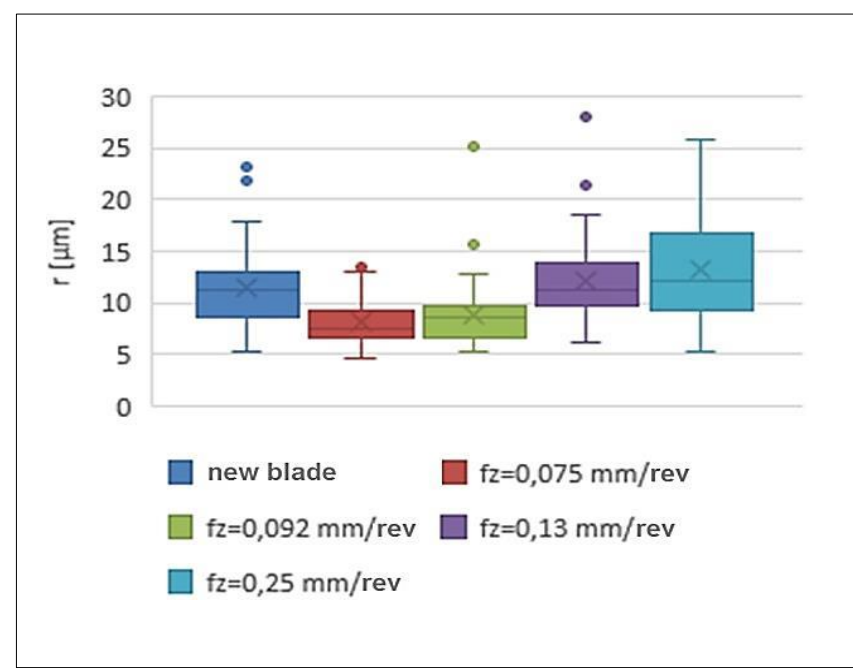

Fig. 6. List of the results of the measurement of the radius of the rounding of the cutting edge

Obtained 3D models were also used to observe the changes in microgeometry of the cutting insert, focusing mainly on the cutting edge radius. To this end, 50 crosssections were extracted (fig. 7). Geometric elaboration of the profiles obtained was carried out automatically in the software. The results obtained together with the results of the measurement of a new insert (nominal geometry) are shown in fig. 6 . The graph shows a clear decrease in the value of the tested parameter for the lowest feed values, i.e. for stages II and III (see table). The possible reason for this was the formation of accretions. Increasing the rounding radius of the cutting edge was noted for the largest feed values, i.e. in stages I and IV.

The observed wear of the cutting inserts was not large enough to reliably provide the values of the parameters specified in the PN-ISO 3685 standard. No abrasion was observed on the flank surface.

Fig. 8 shows a groove origin on the rake face, however, this is not confirmed neither in the 3D model analysis (fig. 5) nor in the extracted profile of the insert geometry crosssection. 


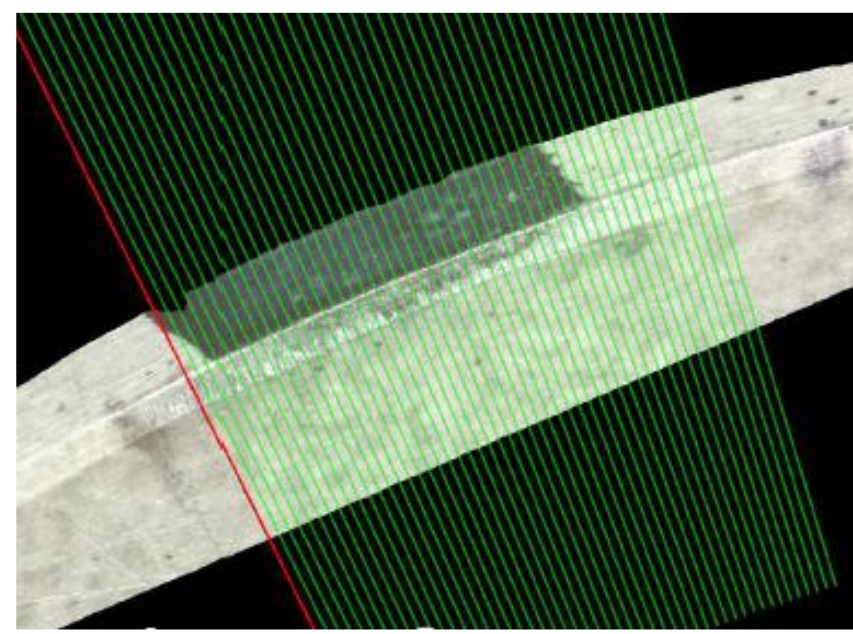

Fig. 7. Visualization of the arrangement of the cross-sections of the cutting insert. Profile numbering - ascending from the left side

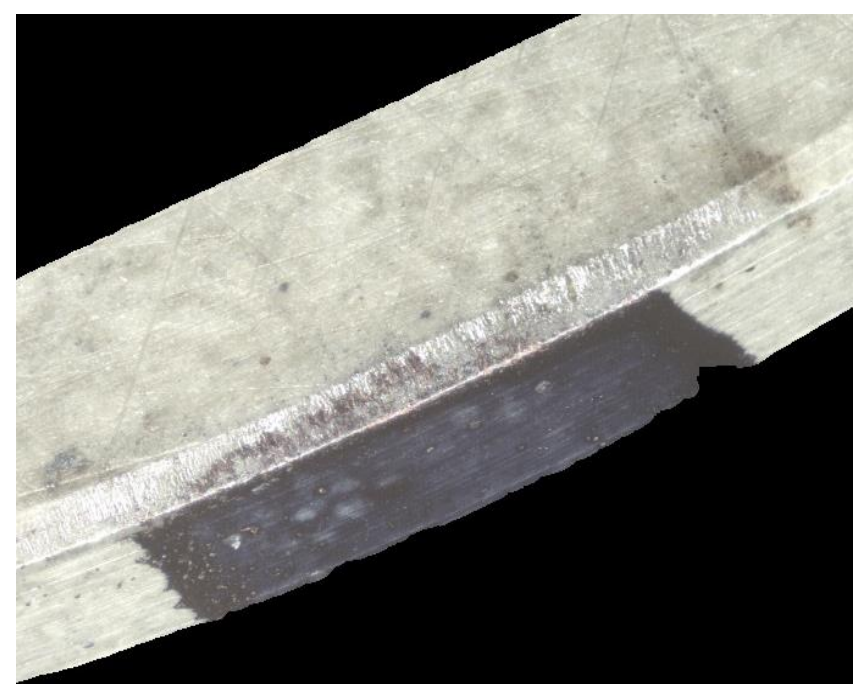

Fig. 8. Image of the cutting insert after the fourth machining step

\section{Conclusions}

The article presents the possibilities of analysis of the turning process in terms of machined surface inequalities and tool geometry changes.

In the analysis of the results, attention was paid to the difference in surface irregularities, especially $R z$ and $S z$, which has a source in profile measurement properties - part of the area on the measured surface is bypassed by the measuring tip. Performing an area measurement allows all measurable surface asperities to be taken into account.

The obtained image was characterized by a real color reproduction, which allowed to find a groove origin on the rake surface (fig. 8 ).

The measurement resolution was sufficient to observe changes in the geometrical features of the tested tool (fig. 4 and fig. 7), although the wear of the tool itself, defined as abrasion of the flank surface, did not reach measurable values.

Presented results of the research carried out in the research task no. 02/22/DSPB/1432 were financed from the grant for science, awarded by the Ministry of Science and Higher Education.

The measuring devices for the needs of the conducted research have been made available by the ITA company from Skórzewo near Poznań.

\section{REFERENCES}

1. Chwalczuk T., Rybicki M., Korzeniewski D., Przestacki D. "Surface roughness after turning of aircraft materials". Mechanik. 10 (2016): pp. 1312-1313.

2. Segebade E., Zanger F., Schulze V. "Influence of different asymmetrical cutting edge microgeometries on surface integrity". 3rd CIRP Conference on Surface Integrity. Procedia CIRP. 45 (2016): pp. 11-14.

3. Stahl J.E., Schultheiss F., Hagglund S. "Analytical and experimental determination of the Ra surface roughness during turning". 1st CIRP Conference on Surface Integrity. Procedia Engineering. 19 (2011): pp. 349-356.

4. Wieczorowski M. „Teoretyczne podstawy przestrzennej analizy nierówności powierzchni”. Inżynieria Maszyn. 18, 3 (2013).

5. Danzl R., Helmli F., Scherer S. "Focus Variation - a robust technology for high resolution optical 3D surface metrology". Journal of Mechanical Engineering. 57, 3 (2011): pp. 245-256.

6. Hiersemenzel F. et al. "Areal texture and angle measurements of tilted surfaces using focus variation methods". Universite de Savoie, Loughborough's Institutional Repository, 2012.

7. Leach R.K. "Optical Measurement of Surface Topography". Berlin: Springer-Verlag, 2011.

8. Brzozowski D., Wieczorowski M., Gapiński B. „Pomiar geometrii i ocena powierzchni narzędzi za pomocą mikroskopu różnicowania ogniskowego". Mechanik. 11 (2017): pp. 1020-1022.

9. Grossmann D., Hofer A., Brzozowski D., Wieczorowski M., Ziętkiewicz P. „Zapewnienie jakości w produkcji łopatek turbin Optyczna metrologia 3D w przemyśle lotniczym". Mechanik. 12 (2015): pp. K80-K83.
Translation of scientific articles, their computer composition and publishing them on the website www.mechanik.media.p by original articles in Polish is a task financed from the funds of the Ministry of Science and Higher Education designated for dissemination of science.

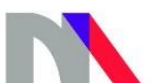

Ministry of Science and Higher Education

Republic of Poland 